\title{
Re-inserting and re-politicizing nature: the resource curse and human-environment relations
}

\author{
Matthew Pritchard ${ }^{1}$ \\ McGill University, Canada
}

\section{Introduction}

The study of the relationship between natural resource wealth and development has moved up and down the ladder of research, policy and investment priorities over the past sixty years. Despite significant attention in academic and practitioner circles, there is an overwhelming lack of consensus about the link between natural resources and development. Specifically, throughout the latter part of the twentieth century there has been a significant shift away from the perception of resource wealth as a key component of macroeconomic reform (cf. Viner 1952; Rostow 1961), to new interest in the so called 'resource curse', and the negative impacts that an abundance of, or dependence on, natural resources can have on economic stability (Collier and Hoeffler 1998; Doyle and Sambanis 2000; Fearon 2004), economic growth (Auty 2001; Sachs and Warner 1995) and the development of accountable political institutions (Ross 2001b; Wantchekon 1999). ${ }^{2}$ At the same time, the remarkable attention given to this potential 'curse' has precipitated a large body of work that challenges the data and statistical methods that link resource wealth with negative development outcomes. The theoretical foundation and relevance of studies that use reductive economic models to assert the 'resource curse' has been questioned (cf. Basedeau and Lay 2009; Brunnschweiler and Bulte 2009; Rosser 2006). On the one hand, a number of authors have continued to work on developing quantitative modeling (cf. Lujala et al. 2005; Ross 2004a, 2006). There has also been a small but growing body of work that challenges the overall premise of the resource curse, and also arguing that any revealed correlations cannot account for the complex relationship between human-environment and institutional relations (cf. Basedeau 2005; Cramsey 2008; De Soysa 2002; Rosser 2006). Rather than striving to refine existing variables to better operationalize the links between the presence of resources and specific development outcomes, these studies question whether the resource curse exists in the first place.

This article draws on key literature from the field of political ecology to demonstrate how the concept of 'nature' has been completely removed (in name and practice) from the debate surrounding the 'resource curse. ${ }^{3}$ Political ecology's deconstruction of 'nature' and its insistence that it is a socio-political and economic entity offers an effective tool to further refine the theoretical foundation and practical application of the resource curse (cf. Blaikie 1985; Blaikie and Brookfield 1987). ${ }^{4}$ Re-politicizing and re-localizing 'nature' provides an essential addition to existing theories by emphasizing local livelihood practices and the link between our understanding of natural resources and historically-rooted discourses of 'proper-use.' Approaching nature and natural resources as socially produced and dynamic political and economic entities allows us to not only better understand human-environment relations within and between scales, but in doing

\footnotetext{
${ }^{1}$ Matthew F. Pritchard is a PhD student in the Department of Geography at McGill University, Montreal, Canada. Email: matthew.pritchard "at" mail.mcgill.ca. Special thanks to Drs. Jon Unruh, Khalid Medani and Simon Batterbury, as well as to anonymous reviewers for their valuable comments on earlier drafts of this article.

${ }^{2}$ The concept of the 'resource curse' initially emerged to link wealth of natural resources to slow economic growth, and the argument that "resource-rich countries tend to grow more slowly than resource poor ones" (Brunnschweiler and Bulte 2006:2). However, this preliminary definition has been expanded to include arguments that resource wealth in developing countries can also lead to the stagnation of transparent and accountable political institutions, and negatively impact the onset and duration of conflicts. For the purpose of this study, we understand the 'resource curse' as those arguments and concepts that link resource wealth, abundance or dependence to negative impacts on socio-economic, political and security institutions.

${ }^{3}$ The focus of this article is not to provide a general critique of the resource curse from the perspective of political ecology (such critiques can be found in cf. Le Billon 2001b, 2005, 2007; Korf 2011; Watts 2007). Rather, this article uses specific (classic) arguments from political ecology to demonstrate that the concept of nature has been removed from qualitative and quantitative studies of the resource curse. Furthermore, throughout this article I understand and define political ecology as an analytical tool (or lens) that provides a multi-scalar and diachronic approach to understanding the environment as an arena where different actors with different political powers compete for access to and control over resources.

${ }^{4}$ In the interest of simplicity, from this point on I drop the use of quotations around 'nature' but continue to refer to nature as a concept that is not only socially produced, but also evolves simultaneously along multiple fronts as overlapping and competing expressions of political, economic and cultural relations.
} 
so, separates qualitative and quantitative models away from restrictive visions of what counts as legitimate and illegitimate resource extraction.

Given significant variations in the data, analytical models and theoretical frameworks that dominate literature on the resource curse, the article begins with a brief overview of the key theories that link resource wealth with slow or negative economic growth, the stagnation of transparent and accountable political institutions, and the onset and duration of conflict. Second, given the implications any form of 'curse' has for developing states and policy reform, I follow with a summary of the key critiques that refine specific quantitative models, as well as those that challenge the statistical validity and theoretical foundation of the resource curse. Finally, building on these theoretical and critical frameworks, I demonstrate how a multiscalar and diachronic approach to understanding multiple natures as expressions of human-environment relations provides an additional (and essential) perspective to current literature on the resource curse. When situated within an understanding of the environment as an arena where multiple actors with different political powers compete for access to and control over resources, the reduction of socio-economic, political and institutional relations to the presence or absence of natural resources not only de-politicizes and de-localizes complex historically rooted human-environment relations, but also ignores the 'social construction' of nature as used to capitalize and control it.

Although this article demonstrates that understanding human-environment relations as expressions of socio-political and economic structures provides an important addition to existing literature, I do not argue that relativist perspectives of the resource curse should be elevated above the contributions of positivist modelling approaches. Rather, the divergent methods and advantages of qualitative and quantitative analyses provide a means to triangulate human-environment relations within and between scales and geographic contexts. Although it is important to critique the quality of quantitative data, the strength of correlations, and the policy-relevance of any conclusions, quantitative models remain important. While the article repeatedly problematizes the reduction of complex socio-political, economic and historically rooted practices to mutually exclusive and measurable 'variables', my goal is to refine rather than undermine the existing and potential contributions of positivist models. Indeed, literature on the resource curse has been undermined by a desire to elevate qualitative approaches over the quantitative, or vice versa.

The ideal approach is probably somewhere between macro and micro level analyses and the different approaches, with attention to simplistic interpretations of reality. On the one hand, large-N studies provide an important method of comparing and contrasting specific experiences within and between countries at different periods in time. On the other hand, these models are necessarily disconnected from the complex dynamics that inform the evolution of individual and institutional relations within and across scales. Microlevel analyses that re-politicize and re-localize the concept of 'nature' can enhance (rather than replace) the theoretical and practical application of existing models that pre- and postdict social, political and economic relations. This progressive contextualization (Vayda 1983) of the macro through the micro (and vice versa) provides an essential method of developing models that are capable of explaining variation, and therefore, refining public policies that can be implemented across scales and countries.

\section{Resources, economics, institutions and conflict}

Prior to the 1980s, international development narratives were rooted in the belief that natural resource wealth was advantageous for sustainable growth (Lewis 1955; Viner 1952). Based on modernization theory, resources were seen as essential means to initiate the industrial take-off required to transform underdeveloped economies (Rostow 1961). Specifically, modernization theorists argued that resource wealth facilitates industrial development by increasing incentives for external and internal investment, which in turn leads to new markets (Rostow 1961). Although this view of resources as the essential drivers of industrial growth dominated initial thinking on international development, as early as 1950 a number of economists noted that resource wealth can also pose a serious threat to long-term macroeconomic reform. Specifically, Prebisch (1950) and Singer (1950) argue that declining terms of trade for primary commodities on the international market presents serious obstacles to resource dependent economies. Similarly, Hirschman (1958) states that resource exploitation does not lead to the production linkages or higher multiplier effects that are required for the industrial 'take-off' central to modernization theory. In retrospect, these critiques provide the first warnings that natural resource wealth could potentially present a significant obstacle to development.

Building on earlier works by Singer (1950), Prebisch (1950) and Hirschman (1958), in the late 1990s and early 2000s a number of economists, economic geographers and political scientists began to link natural resource wealth to decreases in economic growth (cf. Auty 2001; Sachs and Warner 1995), the stagnation of transparent and accountable political institutions (cf. Ross 2001a; Snyder and Bhavani 2005; Wantchekon 1999), and the onset, duration and intensity of civil war (cf. Collier and Hoeffler 1998; Fearon 2004; Lujala 2010). Labelled as the 'resource curse,' the initial and continued attraction of theories that link natural resource wealth and negative development outcomes cannot be separated from the fact that they are easily situated alongside oversimplified visions of the developing world as incongruent with 'Western' experiences (Ferguson 2006). These theories contradicted conventional wisdom on both the benefits of resource wealth 
and risks of environmental scarcity. Although a complete breakdown of the literature on the resource curse is a worthwhile, if not frustrating challenge (due to significant variations in models, variables and theories), given the limited space and scope of this article, I restrict this section to a brief overview of the main theoretical contributions. ${ }^{6}$ I have divided the key arguments into three overlapping categories of economic growth, the quality of institutions, and finally, the onset, duration and intensity of conflict. Although these categories provide an effective method of summarizing the narratives that predominate in literature on the resource curse, it is essential to acknowledge that there is significant overlap between the effects that resources have on socio-economic growth, state institutions and peace, and that the precise interplay between constituent factors is far from known (Basedeau 2005).

First, building on the initial arguments by Singer (1950) and Prebisch (1950), a number of authors argue that resource wealth can significantly hinder economic growth in developing countries (cf.; Auty 1994; Karl 1997; Lujala 2010; Sachs and Warner 1995; Wheeler 1984). From this perspective, reliance on natural resources can impede the development of alternative tradable sectors, stimulate unwise investments by the state, and increase an economy's vulnerability to external shocks through a process known as 'Dutch disease' (Basedeau 2005). ${ }^{7}$ Where macroeconomic reform is driven (in theory) by long-term growth in manufacturing, Dutch disease can lead to significant reductions in the overall terms of trade and relative price of exports. Overall, Dutch disease can leave already weak economies vulnerable to external shocks, encourage excessive borrowing based on the collateral provided by natural resources, and increase import substitution (Basedeau 2005; Ross 2004a).

Second, growing interest in the potential inverse relationship between resource wealth and economic reform led a number of authors to shift from an explicit focus on economic growth, to a focus on links between resource wealth and the quality of state institutions (cf. Okhrhlik 1999; Ross 2001a; Wantchekon 1999). Similar to the potential impacts of Dutch disease, the relationship between resource wealth and political institutions is rooted in Mahdavy's (1970) concept of the 'rentier state.' Here, the regular and substantial funds obtained from natural resources necessarily reduce incentives for ruling elites to develop strong reciprocal state-society relations (Karl 1997; Luciani 1987; Ross 2001b). ${ }^{8}$ Decreased accountability leads to a significant decline in bureaucratic capacity, re-enforces existing patron-client relations, and encourages governments to expand the size of the public sector (Wick and Bulte 2006). The concept of the rentier state, therefore, demonstrates how resource wealth can be removed from the economy, exacerbate the impacts of Dutch disease, and decrease a state's abilities and incentives to form strong, accountable political institutions.

Third, in addition to the literature that links natural resource wealth to a lack of economic growth and weak socio-political institutions, over the last fifteen years, a large number of authors have turned to the resource curse in an attempt to explain the onset, duration and intensity of sub-state conflict (cf. Collier and Hoeffler 1998, 2004; Fearon and Laitin 2004; Humphreys 2005; Le Billon 2001, 2007; Lujala et al. 2005; Ross 2004a). Again, despite significant overlap between theories, it is helpful to organize the main contributions from this popular body of literature into two sub-categories: those that link natural resource wealth with the onset of conflict, and those that link specific characteristics of particular resources with variations in the duration, intensity and type of conflict.

On the one hand, the literature that endeavours to trace the relationship between resource wealth and the onset of civil war draws on behavioural and rational choice perspectives in an attempt to explain the motivations and abilities different actors have to rebel. Specifically, behavioural perspectives stress the link between resources and the motivation for conflict. Referred to as the grievance model (Collier and Hoeffler 2004; De Soysa 2002), a behavioural approach highlights the ways in which resource wealth can exacerbate existing economic, political, ethnic and religious inequalities to precipitate large-scale conflict in developing countries (Ross 2002; Rosser 2006). Conversely, rational choice perspectives highlight the existing and potential economic opportunities that rebellion or insurgency offer participants and supporting institutions

\footnotetext{
${ }^{6}$ For a more detailed overview of the resource curse see Basedeau (2005), Karl (1997), Le Billon (2007), and Rosser (2006).

${ }^{7}$ 'Dutch disease' is the process by which resource wealth can lead to increases in domestic prices and appreciation in local currencies, which in turn discourage external investments in the manufacturing sector (Lujala 2010; Sachs and Warner 1995; Shaxson 2005). In turn, increased dependence on natural resources can force human and financial capital away from a less competitive and shrinking manufacturing sector (Wick and Bulte 2006).

${ }^{8}$ The theory of the rentier state is based on the belief that resource rents reduce a government's need to tax its citizens, and in doing so, dramatically decrease the accountability of the political elite (Basedeau and Lay 2009). This process allows the state to disconnect from its citizens (Di John 2007), which in turn increases the ability and incentives of the ruling elite to act in predatory ways (Reno 2000).
} 
(Rosser 2006). ${ }^{9}$ Differing from studies that concentrate on specific grievances, this greed-based model centres on the financial opportunities that natural resource wealth presents for potential rebels and their supporters (Collier and Hoeffler 1998; Collier 2000). Furthermore, impressive contributions by Ross (2004b) and Fearon and Laitin (2004) argue that not only do rebels loot natural resources and sell future exploitation rights to fund conflict, but also the prevalence of natural resources reduces incentives to reach a peaceful settlement. In other words, resource wealth can facilitate the continuation of conflict by providing both the means and motivation for rebellion.

On the other hand, although the greed-grievance models were among the first theories to link natural resource wealth to specific sub-state conflicts, empirical studies quickly transcended postdictions of the onset of civil war, to determine the impacts that particular characteristics of different resources (e.g. oil, water, diamonds) have on the duration, intensity and type of conflict. For example, Ross (2004b) argues that the legality, lootability and obstructablity of natural resources affect the emergence and continuation of civil war. Conversely, Le Billon $(2001 \mathrm{~b}, 2008)$ states that the spatial distribution of resources in relation to the centre of power (proximate versus distant) and the methods of extraction (point source versus diffuse) determine the probability and type of conflict. ${ }^{10}$

Building on these two sub-categories, the literature linking natural resources and conflict is progressing along two different fronts: (a) those studies that postdict the motivations and abilities different actors have to rebel; and (b) those studies that continually parse out and refine variables to strengthen the statistical links between characteristics of specific resources and human behaviour. Having acknowledged these different trends, it is surprisingly difficult to not only separate between the various literatures and subliteratures, but also to determine how different authors employ divergent and overlapping analytical perspectives. For example, as the overwhelming majority of literature on the resource curse explains the correlations between similar (if not identical) independent and dependent variables by drawing on different data sets, and interpreting results through a mixture of perspectives including rational choice, institutional (state-centric), behaviouralist, dependency, and neo-structuralist. All these studies emerge as re-workings of different variables, rather than critical efforts to compare and contrast correlations according to theories that explain the evolution of structure and agency within and across scales of human-environment relations.

\section{Critiques of the resource curse}

Having provided a brief overview of the main arguments that predominate throughout literature on the resource curse, this section introduces the key critiques that have emerged to refine and challenge the analytical frameworks and theoretical foundations of the potential links between resource wealth and specific socio-political and economic outcomes. Given that the main purpose of this article is not to provide an exhaustive summary of the literature, but to demonstrate that the concept of nature as a social and political construct has been removed from our understanding and approach to the resource curse, I have grouped the existing critiques into two categories. ${ }^{11}$ On the one hand, a number of authors work within the analytical framework laid out by the resource curse (that empirical data and statistics can and do measure humanenvironment relationships within and across contexts) to critique the data, models and robustness of specific results (cf. Hegre and Sambanis 2006; Le Billon 2001b; Lujala et al. 2005; Ross 2006). On the other hand, a small but growing body of literature challenges the theoretical foundation and overall relevance of the resource curse by questioning our ability to capture, understand and explain the complex interplay between contextually rooted and overlapping socio-political and economic variables (cf. Basedeau 2005; Boschini et al. 2007; Brunnschweiler and Bulte 2009; Rosser 2006; Wick and Bulte 2006).

Firstly, beyond simply concluding that a country's natural resource base can hinder development, a number of authors (cf. Humphreys 2005; Lujala 2009; Ross 2006; Snyder and Bhavani 2005) attempt to refine correlations in order to increase the robustness of results, as well as to determine the directions and weights of causality. Beyond the importance of rigor and reproducibility, this desire to clarify existing correlations emerges as a direct result of the fact that data on natural resources in developing economies are imprecise (Ross 2006), are not available in the quality and quantity required for effective and robust

\footnotetext{
${ }^{9}$ Here, rational choice perspectives "emphasise self-interested behaviour on the part of political actors" (Rosser 2006: 13). Differing from behavioural perspectives that centre on the irrational or emotional behaviour of actors, a rational choice approach portrays "political actors as rational utility-maximising individuals" (Rosser 2006: 15).

${ }^{10}$ For further information on the relationship between types and specific characteristics of resources and conflict, see Auty (2001), Boschini et al. (2007), Le Billon (2001a), Ross (2003).

${ }^{11}$ Although the critiques introduced in this section apply to the economic, institutional and conflict-related aspects of the resource curse, I note that the supporting literature draws primarily (but not exclusively) on citations from conflict theory. First, the link between conflict and resource wealth has emerged as the most recent iteration of theories linking resource wealth and social change. As such, it has garnered significant attention in both the academic and public spheres, and spurred vigorous debate. Second, an extensive list of how the different critiques introduced in this article are supported by economic, institutional and conflict theorists would disrupt the flow of the article, and detract from the main arguments.
} 
correlations (Basedeau 2005; Rosser 2006), and are often only available for short term periods (Cramsey 2008). Furthermore, these critiques argue that the statistical links between resource wealth and specific development outcomes are undermined by the fact that most authors use different ways of measuring similar, if not identical, independent and dependent variables. For example, although a number of works correlate natural resource wealth with the onset of civil war, the specific results (and therefore theoretical interpretations) from different models vary significantly according to which of the four main civil war databases (cf. Collier and Hoeffler 2004; Elbadawi and Sambanis 2002; Fearon and Laitin 2003; Gledistsch et al. 2002) the authors use (Di John 2007). In addition to significant variations within and between data sets, Ross (2006) demonstrates that the overwhelming majority of studies on the resource curse;

(a) base their models on endogenous independent variables

(b) fail to separate between correlation and causation

(c) do not determine the direction of correlations

(d) do not test the robustness of their results.

Here, Ross's (2006) impressive contribution demonstrates how shortcomings in specific analytical models account for differences between interpretations and theories of the resource curse. However, despite attempts to improve the quality of the data and measurements, these critiques (cf. Hegre and Sambanis 2006; Lujala 2009; Ross 2006;) remain rooted in the belief that better data and more rigorous methods can remove any externalities from the equation. From this perspective, specific independent variables can be refined into smaller sub-categories in order to increase reliability, replicability and robustness. In other words, rather than question the theoretical premise of literature that links natural resource wealth to the onset and duration of conflict, continuously refining the variable (resource) under investigation according to type (Ross 2006), location (Le Billon 2001b), method of extraction (Auty 2001), and a myriad of other characteristics, can improve the link between resource wealth, economic decline, weak institutions and conflict.

Secondly, building on those critiques that refine the methods but not the theoretical framework of the resource curse, a growing body of work argues that the existing statistical models not only fail to establish a causal link between resources and specific outcomes (i.e. weak institutions, stagnant economies and conflict), but more importantly, that adjusting the data to better measure abundance versus dependence dramatically impacts the strength and direction of correlations. First, in line with the assumption that the data, variables and models can be refined to strengthen results, Alexeeve and Conrad (2008), Brunnschweiler and Bulte (2009), and Lederman and Maloney (2007) argue that analysis of more accurate data actually reverses the link between resource wealth and development, and demonstrate that resources have a positive impact on social relations and political institutions. Specifically, simply distinguishing between resource abundant and resource dependent economies dramatically changes the correlations and the theories that link resource wealth with specific social, political and economic outcomes (Basedeau and Lay 2009; De Soysa 2002; Rosser 2006). Although often treated as synonymous, resource dependence refers to an overwhelming reliance on resource rents (no matter how small the sector) as part of a national economy. Conversely, resource abundance refers to the total value of resources available within a country. According to Basedeau and Lay (2009: 760);

...dependence means that rents from resources are the most important source of income relative to other value adding activities, while abundance or wealth refers to the absolute amount of resource rents available in per capita terms.

On the one hand, differentiating between resource abundance and dependence has significant implications for the measurement of independent variables. Here, measuring resource wealth as the ratio of primary exports to GDP (i.e. Sachs and Warner 1995) captures dependence rather than abundance, which in turn alters the theoretical explanations used to link wealth with specific outcomes. For example, Collier and Hoeffler's (1998) 'greedy rebel' hypothesis is more likely to emerge in environments with a large absolute amount of resource rents (abundance) that increase the potential payoffs of large-scale rebellion (Basedeau and Lay 2009). On the other hand, differentiating between resource abundance and dependence has a significant impact on the strength and direction of correlations between independent and dependent variables. Indeed, by simply differentiating between abundance and dependence, Ding and Field (2005) demonstrate that resource abundance has a positive effect on economic growth, while Brunnschweiler and Bulte (2009) argue that resource abundant countries are less likely to experience civil war.

The fact that different - and arguably more accurate - measures of resource wealth dramatically alter the outcomes of specific models highlights the second shortcoming of literature on the resource curse. Specifically, the overwhelming majority of articles confuse correlation with causation (Di John 2007; Ross 
2006; Rosser 2006). Although a number of studies argue that resource dependence is correlated with corruption, or 'abundance' with economic decline and the duration of conflict, even with the addition of timelagged variables these models do not prove causation (Ross 2004a). Furthermore, beyond debates over correlation versus causation, researchers have paid little attention to the direction of the correlations that link resource wealth with specific socio-political and economic outcomes. As such, the majority of studies do not account for reverse causality (Ross 2006). Finally, despite strong and robust correlations, it is possible, and highly likely given the overlapping and interdependent nature of socio-political and economic development, that any links between natural resource wealth and specific outcomes (both negative and positive) emerge as a result of multiple intervening variables, rather than those selected to measure economic growth, institutional strength, and the onset, duration or intensity of conflict (Ross 2004a, Basedeau 2005; Rosser 2006; Di John 2007).

Third, given that the probability of the resource curse is lower than previously thought ( Basedeau 2005; Ross 2003), and that the data can be adjusted to falsify (if not completely reverse) existing results (Ding and Field 2005), a number of authors question the validity and usefulness of the resource curse paradigm (cf. Brunnschweiller and Bulte 2009; Hagmann 2005; Watts 2007). Although we have seen that Le Billon (2001b), Ross (2006), and Lujala (2009) argue that refining specific variables and statistical methodologies can increase the strength of correlations and robustness of results, we must question the extent to which parsing out data reduces complex variables to restrictive categories that fail to explain real-world phenomena. Indeed, the desire to increase the validity of statistical analyses by further refining independent variables has led a number of authors (cf. Cramsey 2008; Rosser 2006; Watts 2007) to reject the premise that complex social, political and economic relations can be quantified to 'measure' and predict humanenvironment relations. Specifically, ex-post analyses that ignore null cases necessarily produce incomplete conclusions that ignore "a more holistic view on [sic] the complex interactions between natural resources and human behaviour" (Hagmann 2005: 10). Deductive statistical analyses that produce theoretical conclusions about human-environment relations are unable to explain the complex impacts of socially constructed and dynamic variables such as agency, ethnicity, violence and nature (Keen 2012). ${ }^{12}$ In other words, these authors argue that the inherently reductive nature of quantitative models cannot adequately measure or explain the influences that social forces have on different development outcomes. ${ }^{13}$ For example, when studying the impacts of the rentier state, the economic, institutional and conflict-oriented models do not adequately account for the stabilizing and beneficial effects that resource rents can have on political institutions, physical security and macro-economic growth. While we have seen that resource rents can create challenges for political and economic reforms, they also increase opportunities for direct foreign investment, and provide the ruling elite with the means to offset the indirect negative effects of unequal access to goods and services. Furthermore, resource rents provide elites with the income required to combat the incentives and opportunities for rebellion through significant increases in spending on security (Snyder 2006), public sector employment, and external financial and military support (Basedeau and Lay 2009; Herb 2005). Finally, although Reno (2000) argues that resource rents reduce the need for a social contract, and therefore enable governing elites to act in predatory ways, such a disconnect between the state and society can also reduce the likelihood that citizens will rebel. For example, according to Basedeau and Lay (2009), citizens are less likely to revolt against governments that do not levy taxes. Similarly, Okrulik (1999) and Rosser (2006) argue that although political elites may not face social pressure in relation to taxation, they are held to account for spending decisions. These, as well as a number of other caveats to the 'inherent' challenges of rentier states demonstrate the shortcomings of reducing complex socio-political and economic processes to onedimensional models that link resource wealth with specific development outcomes. Rather, focusing on the ways that rents are produced and distributed through these networks demonstrates that beyond stimulating rebellion, resource wealth can simultaneously increase security, stabilize political institutions and facilitate direct foreign investment, while decreasing a government's incentives to promote democratic and economic reforms.

Fourth, the simplistic view that natural resource wealth necessarily has negative impacts on development emerges from a significant oversimplification of state-society relations. An exclusive focus on the roles of government elites suggests that these individuals are unaffected by social pressures (Basedeau and Lay 2009; Rosser 2006), that they always act in predatory or clandestine ways, and that their actions are completely removed from socio-economic, political and historically rooted structural influences. For example, institutional and behavioural visions of the state and potential rebels assume that these actors necessarily have

\footnotetext{
${ }^{12}$ According to Hagmann, "...it is the expression of a positivist perception of social reality that falls short of more sociological thinking about agency, ecology, and physical violence. Environmental conflicts are by definition phenomena situated at the interface between the natural and social spheres. However, the principles and logic, which operate the interactions between the two, are not spelled out sufficiently." (Hagmann 2005: 17)

${ }^{13}$ A more detailed breakdown of how evidence is produced in the quantitative literature, and how different authors derive theoretical conclusions from these data is beyond the scope of this article, and has been covered in detail by Hagmann (2005) and Rosser (2006).
} 
predatory rather than developmental aims (cf. Reno 2000), while rational choice perspectives "suggest that societies in resource abundant countries are composed of disconnected rational utility maximizing individuals who only join together into organized groups to advance common economic interests" (Rosser 2006: 21). These theoretical perspectives are rooted in negative oversimplifications that tell us nothing about the historical and structural conditions that simultaneously empower and restrict individual actors and institutions across contexts and scales of analysis (Basedeau 2005; Rosser 2006). By continually parsing out variables and failing to situate individual agency and collective action within an historically informed yet malleable structure, predictions from the resource curse literature amount to little more than deterministic views of human-environment and state-society relations. Furthermore, these overt simplifications ignore the ways that socio-economic and political relations are rooted in, and evolve out of, complex and constantly changing interactions between interdependent and contextually situated variables (Basedeau 2005).

\section{Re-politicizing nature and re-localizing actors: nature and the natural resource curse}

Having summarized the main concepts and critical readings of literature on the resource curse, this section draws on classic narratives from the field of political ecology to introduce three new critiques of the potential links between resource wealth and specific obstacles to economic, political and peaceful development. Rather than an attempt to provide an exhaustive list of what political ecology can bring to debates surrounding the resource curse, I demonstrate how the concept of nature as a political, social and economic entity has been removed from on-going debates over the existence and expressions of the resource curse. ${ }^{14}$

As a field of study, political ecology focuses on the evolution of unequal power relations as expressions of site specific political, social, and economic narratives that simultaneously inform and are produced by human-environment relations (cf. Blaikie and Brookfield 1987; Bohle and Fungfeld 2007; Bryant 1998; Peluso and Watts 2001). ${ }^{15}$ When juxtaposed with literature on the resource curse, a political ecological - rather than economic, behaviouralist, or rational choice - perspective provides an alternative and essential way of thinking about the links between state institutions, economic reforms, conflict, and the environment. Political ecology has been critiqued for its dilution of 'traditional' ecological and political theories (Walker 2005), and its practitioners criticized for assuming that "political influences - especially political influences from the outside, from the so-called wider political-economic system - are always important, arguably more important than anything else, and should accordingly be given priority in research" (Vayda and Walters 1999: 168). Its explicit focus on the evolution of human-environment relations within complex socio-political and economic contexts, however, provides an important perspective for understanding the resource curse. According to Harvey (1993: 25);

All ecological projects (and arguments) are simultaneously political-economic projects (and arguments), and vice versa. Ecological arguments are never socially neutral any more than social-political arguments are ecologically neutral. Looking more closely at the way ecology and politics interrelate then becomes imperative if we are to get a better handle on how to approach environmental/ecological questions.

Here, the point is not to challenge the validity of previous conclusions, but to highlight the need for studies that link resources to specific socio-economic and political outcomes to incorporate a critical understanding of nature. For example, in a study of what is often characterized as 'oil violence' in Nigeria, Watts (2007) deconstructs specific instances of conflict to demonstrate that violence emerges out of complex socio-political, economic and historic inequalities, rather than being due to the mere presence of oil. 'Violence over oil in Nigeria' can be better understood (and therefore addressed), as an expression of deeply rooted political, economic and social factors that often pre-date the discovery of oil. Understanding and addressing specific social, political and economic challenges requires that we re-insert the concept of nature as a socially produced and historically rooted phenomena that emerges as an expression of political and economic relations into our analyses of the resource curse.

While a number of other authors approach the resource curse from a 'political ecology' perspective, their studies have not always focused on why a critical deconstruction of nature is important to our

\footnotetext{
${ }^{14}$ For a more comprehensive overview of how different perspectives from political ecology are used to approach the resource curse, see Le Billon (2001b, 2005, 2007), Korf (2011), Peluso and Watts (2001), and Watts (2007).

15 See footnote 2 on page 1 for a definition of political ecology.
} 
understanding of the potential links between resource wealth and specific development outcomes ${ }^{18}$ Le Billon's (2001b, 2005, 2007) notable application of political ecology to these issues successfully problematizes a wide range of quantitative approaches used to understand them, but does not deconstruct the meaning of 'nature' used across scales, or the ways that human-environment relations are simultaneously driven and constituted by individuals and institutions competing for access to and control over resources. ${ }^{19}$

I argue that political ecology's traditional focus on the production of nature provides an essential method of expanding and intensifying the theoretical links between state institutions, economic reforms, large-scale violence, and the natural environment. To accomplish this, I make three interrelated arguments. First, when studying the relationships between conflict and natural resources, political ecology's experience in evaluating and critiquing the field of 'environmental security' provides an essential and readily applicable perspective on current debates on the resource curse. Second, by opening up the environment as a category of analysis (Peet and Watts 1996), a political ecology approach allows us to examine how and why particular forms of knowledge about nature and natural resources predominate and circulate. Specifically, an explicit focus on the evolution of human-environment relations reveals that the concept of 'nature' has been removed - in both name and practice - from the debate surrounding the natural resource curse. On the one hand, removing 'nature' from discourses on human-environment relations conceals, and therefore de-politicizes, its construction. On the other hand, ignoring how and why nature is produced obscures the ways in which environmental crises evolve as political and economic narratives deployed to modify access to and control over resources. Third, the trans-scalar and multi-actor oriented approach required to re-insert a critical vision of nature into our understanding of the resource curse demonstrates that an exclusive focus on the actions of states, elites, and potential rebels in resource-rich environments removes local actors from the evolution of human-environment relations, and in doing so, de-localizes site-specific socio-political and historically structured relations. In order to provide an analytically rigorous and effective starting point that integrates discourses on the socio-political and economic evolution of human-environment relations with the historical geography of material practice (Harvey 1993), we need to re-insert nature into our understanding of the resource curse. Only by re-politicizing and re-localizing nature, can we understand and address complex multi-scalar relations that simultaneously create and are created by wider political, economic and historical structures that influence activities within and between contexts (Vayda 1983).

On the first point, one of the most interesting aspects of literature on the resource curse (and indeed part of the reason it is so popular) is that it not only directly contravenes traditional theories that link resource wealth and economic growth, but also contradicts previous arguments that tie resource scarcity (rather than abundance) to conflict. Similar to the sub-literature on the relationship between resource wealth and civil war, authors from the field of environmental security (cf. Baechler 1998, 1999; Homer Dixon 1991, 1994) also use empirical data to link a country's natural resource base to the onset of conflict. In direct contrast with the current focus on abundance and dependence, however, an 'environmental security' perspective argues that a scarcity of renewable resources leads to civil war, insurgencies and rebellion (Baechler 1998; Homer-Dixon 1994, 1999). According to Baechler (1998), political, economic, social, territorial and ethnic conflicts emerge as direct manifestations of deeper environmental disputes driven by a lack (rather than abundance) of resources. Despite an initial popularity amongst policy makers in the early 1990s, a number of works rooted in political ecology emerged quickly to critique the link between resource scarcity, degradation and conflict as fundamental oversimplifications of human-environment relations and as deterministic conceptualizations of resource availability and violence (cf. Deudney 1999; Gledistch 1998; Hauge and Ellingsen 1998; Peluso and Watts 2001). From a site-specific perspective, political ecologists overwhelmingly reject the "automatic and simplistic linkages between increased environmental scarcity, decreased economic activity and migration that purportedly weaken states and cause conflicts and violence" (Peluso and Watts 2001: 5). Given this conclusion, I argue that critiques of the reductive link between human-environment relations and large-scale conflict can be extrapolated from their initial connection with resource scarcity, to current narratives surrounding the deleterious effects of dependence and abundance. Applying critiques of resource scarcity to challenge contemporary arguments surrounding resource wealth is possible not only because environmental security and the resource curse use similar analytical models to predict and explain socio-political and economic outcomes, but also because in both cases, a reductive understanding of human-environment relations fails to identify the ways in which natural resources are capitalized, "distributed, reproduced and fought over in the course of shaping and being shaped by patterns of accumulation" (Peluso and Watts 2001: 5). In other words, literature that attempts to link resource scarcity or resource wealth to conflict, weak institutions and economic decline ignores the site-specific and hierarchical production of human-environment

\footnotetext{
${ }^{18}$ The fact that these studies do not focus on the social construction of nature as related to the resource curse is not a criticism of these noteworthy contributions, as this was not the intended purpose of their respective studies.

${ }^{19}$ Again, this was not the purpose of Le Billon's contributions.
} 
relations through the shifting power bases of different actors and institutions rooted in other forms of social struggle (Bohle and Fungfeld 2007). ${ }^{20}$

Secondly, moving beyond an exclusive focus on the link between resource scarcity or resource abundance and conflict, deconstructing the socio-political and economic foundation of human-environment interactions requires a detailed understanding of nature. Here, on-going discussions of the resource curse have ignored the concept of nature as an expression of un-equal and evolving relations between social and physical entities. Rather than understanding nature and natural resources as produced through socioeconomic, political, and historical relations, specific commodities are seen as naturally occurring or 'god given.' This view of resources as existing prior to, and in spite of, socio-economic and political relations ignores the fact that nature is only created through human-environment interaction. According to Escobar (1996: 2);

...for us humans (and this includes life scientists and ecologists) nature is always constructed by our meaning-giving and discursive processes, so that what we perceive as natural is also cultural and social; said differently, nature is simultaneously real, collective, and discursive fact, power, and discourse - and needs to be naturalized, sociologized, and deconstructed accordingly.

By not deconstructing how nature is produced, capitalized, and grouped into distinct commodities through labour and unequal power relations, literature on the curse implies that resources are inherently negative (rather than positive or inconsequential) to development.

Building upon nature as an expression of complex interpersonal and institutional relations, it is also important to acknowledge that referring to a specific phenomenon as socially constructed is not sufficient for development theory or practice (Fearon and Laitin 2000). Rather, a relativist approach requires an understanding of how specific entities are constructed and employed by different actors. To this end, when studying human-environment interactions, it is essential to acknowledge the reciprocal relationships between nature and society. Humans are naturalized through social interaction within a complex structure bounded by the environment. Nature is initially appropriated by labour, and then socialized through its insertion and incorporation into political and economic systems of control (Bryant 1992; Escobar 1996, 1999). Nature is capitalized, commoditized, and humanized through a scientific gaze, creating a situation where different forms of life are disciplined through new technologies of vision and control (Foucault 1989, 1991; Peluso and Watts 2001). The production of nature cannot be separated from the technocratic ways in which "increasingly vast domains of daily life are appropriated, processed, and transformed by expert knowledge and the administrative apparatuses of the state" (Escobar 1999: 9). Furthermore, rational discourse transforms 'the environment' into a capitalist nature that is rendered uniform, legible, and manageable by the unequal power relations that characterize the production and dissemination of scientific knowledge. The resulting inequalities in power and knowledge (Foucault 1991) mediate access to nature while normalizing and disciplining human-environment relations (Escobar 1999; Peluso and Watts 2001).

The appropriation of nature through expert knowledge and elite interests highlights a second component of human-environment relations that goes beyond their social construction. Specifically, once understood as socially constructed, we can investigate how different concepts of nature are wielded by individuals and institutions competing for greater access to and control over resources. The theoretical foundation of the resource curse cannot be separated from the ways in which unequal power relations and access to information (knowledge) are mobilized to create environmental 'crises', and the ways that actors capitalize on these inequalities to recommend specific political and economically motivated 'solutions.' Beyond simply understanding nature and natural resources as products of social, political and economic relations, it is essential to focus on the ways that narratives of environmental crises (i.e. economic decline, weak political institutions and sub-state conflict) are mobilized by powerful actors to determine notions of 'proper use.' When nature and resources are understood as socially produced and commoditized entities, the definition and expression of specific problems, as well as the policies required to 'resolve' these issues emerge as necessarily political and market-based processes grounded in overlapping and competing visions of 'scientific facts' (Bryant 1992; Escobar 1999; Foucault 1989). A statistical approach to 'measuring' and 'defining' the relationship between natural resources and development cannot be separated from the ways in which these narratives are created and deployed to increase access to and control over limited resources. In the case of the resource curse, Western narratives of how resources should be used to promote 'positive'

\footnotetext{
${ }^{20}$ Here, I note that an increasing number of authors are providing site-specific analyses of how economic, political and security crises related to natural resources must be located within historically rooted power relations and multi-scalar analyses that account for overlapping systems of resource access use and management at the local, regional, national and international levels (cf. Keen 2012; Onuoha 2009; Richards 2006; Watts 2007).
} 
development appears eerily similar to the ways that colonial powers used 'science' (i.e. soil samples and extension agents) to aggressively implement agricultural systems, and to justify the expulsion of farmers from 'threatened' areas (Blaikie 1985). According to Blaikie and Brookfield (1987), environmental problems exist only because they are constructed and defined as such by different groups. In other words, individuals and institutions exploit unequal access to power and knowledge to produce interventions in humanenvironment relations (Guthman 1997; Peluso 1993).

Given that both nature and narratives of 'proper use' emerge through distinct socio-political and economic conceptions of human-environment relations, we must ask ourselves how different political, economic and security-based crises associated with the resource curse (and their potential solutions) evolve in relation to national security agendas and increasing global competition for vast tracts of land (cf. Borras and Franco 2010; Cotula et al. 2011; Deininger and Byerlee 2012), oil reserves (cf. Hanson 2008; Klare and Volman 2006) and fresh water. At the same time, contextualizing the construction and deployment of 'proper resource use' is not meant to suggest that abundance or dependence do not lead to specific environmental or socio-political and economic challenges (Rocheleau et al. 1995). Rather, given the fact that natural resources are not only socially constructed, but deployed alongside, and as extensions of, specific political, economic and contextually rooted goals, any discussion of the inherent challenges and opportunities for development must be situated within a power-knowledge complex dominated by Western interests.

Thirdly, when using the concept of unequal power relations to deconstruct human-environment interactions, it quickly becomes apparent that the overwhelming majority of literature on the resource curse focuses exclusively on the actions of only the most powerful individuals. Specifically, Reno (2000), Collier (2002) and Lujala (2010) explain resource use in relation to state elites, potential rebels, and international actors with little to no consideration of local populations. On the one hand, the reduction of humanenvironment relations to mutually exclusive sets of actors ignores the ways that these individuals and institutions directly and indirectly support each other. According to Watts (2007: 65), "the very idea of an impermeable membrane separating or opposing two discrete entities - government and rebels - breaks down immediately given the complex and evolving relations of financial, political and military support." On the other hand, an exclusive focus on national level actors ignores and de-legitimizes local individuals and institutions, and as a result, overlooks and undermines the methods of extraction and production that are intrinsic to local livelihoods. As a result, the actions of sub-state, regional and local entities are scaled up into simplistic and often pejorative views of how the rural poor rely on and extract natural resources. Ignoring the socio-political, economic, and historical structures that guide extraction within and across different scales, de-localizes and de-politicizes specific livelihood preferences and methods of production and consumption. It is essential to not only highlight the ability of the poor to contest their plight (Bryant 1992), but also to question the ways in which local, regional and national practices constitute and are produced by one another (Watts 2007). Although necessarily unequal, the power relations that mediate multi-actor interactions with nature are dispersed through formal and informal means of control that result in innumerable points of contact and confrontations between actors and institutions at different scales. As such, any discussion of resource use must be situated within and between the different individual and institutional networks that operate across historically and culturally rooted fields of power (Peluso and Watts 2001) to produce and contest different interpretations of nature.

\section{Conclusion}

Despite the myriad of challenges to the data, methods and theoretical frameworks of literature on the resource curse, the purpose of this article is not to deny that an abundance of, or dependence on, natural resources can have an influence on social, political and economic development. Rather, my goal has been to summarize the main contributions and critiques from the literature in order to demonstrate that the reduction of complex social, political and environmental narratives to a restricted view of human-environment relations has de-politicized and de-localized the concept of nature. Only once we re-introduce a multi-scalar and critical understanding of nature can we begin to move forward by progressively contextualizing the macro through the micro (and vice versa).

Nature and natural resources are constructed within specific social, political, economic and historically rooted visions of human-environment relations, and as such, cannot be separated from competing discourses of 'proper use' mobilized to gain access to and control over resources. Without acknowledging how our understanding of resources is used to justify competing conceptions of access and use, any solutions emerging from qualitative and quantitative approaches are necessarily prescribed by our definition of the problem at hand.

The exclusive focus on elite actors and institutions competing for resources at the national level not only ignores local interpretations and expressions of nature, but also completely removes the livelihood practices of the rural poor (as well as other local and regional entities) from discussions of use, access and management. Drawing on specific narratives (from the field of political ecology) that de-construct the concept of nature as a socio-political entity, I argue that any attempt to understand human-environment 
relations requires express attention to historically situated, multi-scalar relationships between power, knowledge, extraction and production. However, while a number of authors argue that the political, economic, and social evolution of human-environment relations necessarily requires site-specific analysis, I argue that only once nature has been re-inserted into the discussion (or equation) can we begin to read the macrothrough the micro (and vice versa), and achieve an on-going process of progressive contextualization (Vayda 1983).

Reducing complex human-environment relations to specific variables requires an understanding of different socio-political, cultural, economic and historical relations within and between contexts, actors, and institutions. Micro-level analyses need to be situated within the wider political and economic structures that influence activities across time and space. This is a fundamental principle of political ecology. It is especially important to acknowledge that the development and application of effective theories and policies aimed at altering human-environment relations requires an understanding of innumerable variables within and between scales, contexts and theoretical frameworks. The true power of micro and macro-level analyses, therefore, is their respective abilities to simultaneously inform and refine one another. Here, the relevance of studies that quantify and qualify the link between natural resources and development is not their ability to postdict specific outcomes, but to inform how future policies are developed and implemented according to the political and economic goals of specific actors and institutions. As human-environment relations are simultaneously produced and contested across multiple scales, it is essential to compare and contrast various methods and conceptual frameworks to not only explain outcomes, but also predict future opportunities, and to develop practical policy tools that function within and across spatial and temporal contexts.

\section{References}

Alexeev, M. and R. Conrad. 2009. The elusive curse of oil. The Review of Economics and Statistics 91 (3): 586-598.

Auty, R.M. 1994. Industrial policy reform in six large newly industrializing countries: the resource curse thesis. World Development 22(1): 11-26.

Auty, R.M. 2001. Resource abundance and economic development. Oxford: Oxford University Press.

Baechler, G. 1998. Why environmental transformation causes violence: a synthesis. Environmental Change and Security Project Report 4: 24-44.

Baechler, G. 1999. Violence through environmental discrimination: causes, Rwanda arena, and conflict model. Dordrecht. Kluwer Academic Publishers.

Blaikie, P. 1985. The political economy of soil erosion in developing countries. London: Longman.

Blaikie, P. and H.C. Brookfield. 1987. Land degradation and society. New York: Methuen.

Bohle, H.G. and H. Fungfeld. 2007. The political ecology of violence in Eastern Sri Lanka. Development and change 38(4):665-687.

Borras Jr, S. and J. Franco. 2010. From threat to opportunity? Problems with the idea of a code of conduct for land-grabbing. Yale Human Rights and Development Law Journal 13(1): 507-523.

Boschini, A.D. J. Pettersson, and J. Roine. 2007. Resource curse or not: a question of appropriability. Scandinavian Journal of Economics 109(3): 593-617.

Brunnschweiler, C.N. and E.H. Bulte. 2009. Natural resources and violent conflict: resource abundance, dependence, and the onset of civil wars. Oxford Economic Papers 61(4): 651-674. Working paper

Bryant, R.L. 1992. Political ecology: an emerging research agenda in Third-World studies. Political Geography 11(1): 12-36.

Bryant, R.L. 1998. Power, knowledge and political ecology in the third world: a review. Progress in Physical Geography 22(1): 79-94.

Collier, P. and World Bank. 2000. Economic causes of civil conflict and their implications for policy. Washington: World Bank.

Collier, P. and A. E. Hoeffler. 1998. On economic causes of civil war. Oxford Economic Papers 50: 563-573.

Collier, P. and A.E. Hoeffler. 2004. Greed and grievance in civil war. Oxford Economic Papers 56: 563-595.

Cotula, L., S. Vermeulen, P. Mathieu and C. Toulmin. 2011. Agricultural investment and international land deals: evidence from a multi-country study in Africa. Food Security 3: 99-113.

Cramsey, M. 2008. Challenging the curse: creating a new framework for understanding the resource curse. International Politics of Oil. http://jsaw.lib.lehigh.edu/include/getdoc.php?id=2287\&article=1463\&mod (Accessed March 8, 2011).

De Soysa, I. 2002. Paradise is a bazaar? Greed, creed, and governance in civil war, 1989-99. Journal of Peace Research 39(4): 395-416. draft 
Deininger, K. and D. Byerlee. 2012. The rise of large farms in land abundant countries: do they have a future? World Development 40(4): 701-714. draft

Deudney, D. 1999. Environmental security: a critique. In D. Deudney and R. Matthew (eds.), Contested grounds: security and conflict in the new environmental politics. Albany: State University of New York Press. Pp 187-219.

Di John, J. 2007. Oil abundance and violent political conflict: a critical assessment. Journal of Development Studies 43(6): 961-986.

Ding, N. and B.C. Field. 2005. Natural resource abundance and economic growth. Land Economics 81(4): 496-502. draft

Doyle, M.W. and N. Sambanis. 2000. International peacebuilding: a theoretical and quantitative analysis. The American Political Science Review 94(4): 779-801.

Elbadawi, I. and N. Sambanis. 2002. How much war will we see? Explaining the prevalence of civil war Journal of Conflict Resolution 46(3): 307-334.

Escobar, A. 1996. Construction nature: elements for a post-structuralist political ecology. Futures 28(4): 325343.

Escobar, A. 1999. After nature: steps to an antiessentialist political ecology. Current Anthropology 40(1): 130.

Fearon, J.D. 2004. Why do some civil wars last so much longer than others? Journal of Peace Research 41(3): 275-301.

Fearon, J.D. and D.D. Laitin. 2000. Violence and the social construction of ethnic identity. International Organization 54(04): 845-877.

Fearon, J.D. and D.D. Laitin. 2003. Ethnicity, insurgency, and civil war. American Political Science Review 97(01): 75-90. draft

Fearon, J.D. and D.D. Laitin. 2004. Neotrusteeship and the problem of weak states. International Security 28(4):5-43.

Ferguson, J. 2006. Global shadows: Africa in the neoliberal world order. Durham: Duke University Press Books.

Foucault, M. 1989. The birth of the clinic. London: Routledge.

Foucault, M. 1991. Governmentality. In Burchell, G. C. Gordon, and P. Miller (eds.) The Foucault effect. Chicago: University of Chicago Press. Pp 87-104.

Guthman, J. 1997. Representing crisis: the theory of Himalayan Environmental Degradation and the project of development in post Rana Nepal. Development and Change 28(1): 45-69.

Hagmann, T. 2005. Confronting the concept of environmentally induced conflict. Peace, Conflict and Development 6: 1-22.

Hanson, S. 2008. China, Africa, and oil. Council on Foreign Relations. [Accessed March 8, 2011] http://www.cfr.org/publication/9557

Harvey, D. 1993. The nature of environment: dialectics of social and environmental change. Socialist Register 1: 1-51.

Hauge, W. and T. Ellingsen. 1998. Beyond environmental scarcity: causal pathways to conflict. Journal of Peace Research 35(3): 299-317.

Hegre, H. and N. Sambanis. 2006. Sensitivity analysis of empirical results on civil war onset. Journal of Conflict Resolution 50(4): 508-535.

Herb, M. 2005. No representation without taxation? Rents, development, and democracy. Comparative Politics 37(3): 297-316.

Hirschman, A.O. 1958. The strategy of economic development. New Haven: Yale University Press.

Homer-Dixon, T.F. 1994. Environmental scarcities and violent conflict: evidence from cases. International security 19(1): 5-40.

Homer-Dixon, T.F. 1999. Environment, scarcity, and violence. Princeton: Princeton University Press.

Humphreys, M. 2005. Natural resources, conflict, and conflict resolution: uncovering the mechanisms. The Journal of Conflict Resolution 49(4): 508-537.

Karl, T.L. 1997. The paradox of plenty: oil booms and petro-states, Berkeley: University of California Press.

Keen, D. 2012. Greed and grievance in civil wars. International Affairs 88(4): 757-777.

Klare, M. and D. Volman. 2006. The African 'Oil Rush' and US National Security. Third World Quarterly 27(4): 609-628.

Korf, B. 2011. Resources, violence and the telluric geographies of small wars. Progress in Human Geography 35(6): 733-756. 
Le Billon, P. 2001a. Angola's political economy of war: the role of oil and diamonds, 1975-2000. African Affairs 100(398): 55-80.

Le Billon, P. 2001b. The political ecology of war: natural resources and armed conflicts. Political Geography 20(5): 561-584.

Le Billon, P. 2005. Fuelling war: natural resources and armed conflict: London: Routledge.

Le Billon, P. 2007. Geographies of war: perspectives on 'Resource Wars'. Geography Compass 1: 163-182.

Le Billon, P. 2008. Diamond wars? Conflict diamonds and geographies of resource wars. Annals of the Association of American Geographers 98(2): 345-372.

Le Billon, P. 2012. Wars of plunder: conflicts, profits and the politics of resources. New York: Columbia University Press.

Lederman, D. and Maloney, W. F. (eds.) Natural resources: neither curse nor destiny. Washington D.C.: The World Bank and Stanford University Press.

Lewis, W.A. 1955. The theory of economic growth. Wales: George Allen and Unwin Ltd.

Luciani, G. 1987. Allocation vs. production states: a theoretical framework. In H. Beblawi and G. Luciani (eds.) The rentier state. London: Croom Helm.

Lujala, P. 2009. Deadly combat over natural resources. Journal of Conflict Resolution 53(1):50-71.

Lujala, P. 2010. The spoils of nature: armed civil conflict and rebel access to natural resources. Journal of Peace Research 47(1): 15-28.

Lujala P., Gleditsch N.P., Gilmore E. 2005. A diamond curse? Civil war and a lootable resource. Journal of Conflict Resolution 49: 538-562.

Mahdavy, H. 1970. The patterns and problems of economic rent in rentier states: the case of Iran. In M.A. Cook (ed.) Studies in the economic history of the Middle East. London: Oxford University Press. Pp 429-467.

Onuoha, F.C. 2009. Why the poor pay with their lives: oil pipeline vandlisation, fires and human security in Nigeria. Disasters 33(3): 369-389.

Peet, R. M. and M.J. Watts (eds.) 1996. Liberation ecologies: environment, development, social movements. London: Routledge.

Peluso, N.L. 1993. Coercing conservation? The politics of state resource control. Global Environmental Change 3(2): 199-217.

Peluso, N.L. and M. Watts (eds.). 2001. Violent environments. Ithaca: Cornell University Press.

Prebisch, R. 1950. The economic development of Latin America and its principal problems. New York: United Nations Department of Economic Affairs.

Reno, W. 2000. Clandestine economies, violence and states in Africa. Journal of International Affairs 53(2): 433-460.

Richards, P. 2006. An accidental sect: how war made belief in Sierra Leone. Review of African Political Economy 33(110): 651-663.

Rocheleau, D.E. P.E. Steinberg, and P.A. Benjamin. 1995. Environment, development, crisis, and crusade: Ukambani, Kenya, 1890-1990. World Development 23(6): 1037-1051.

Ross, M.L. 2001a. Does oil hinder democracy? World Politics 53(3): 325-361.

Ross, M.L. 2001b. Timber booms and institutional breakdown in Southeast Asia. Cambridge: Cambridge University Press. chapter 1

Ross, M.L. 2002. Resources and rebellion in Aceh, Indonesia. In P. Collier and N. Sambanis (eds.), Understanding civil war. evidence and analysis. Washington: The World Bank. Pp 35-58.

Ross, M.L. 2004a. How do natural resources influence civil war? Evidence from thirteen cases. International Organization 58(01): 35-67. $\underline{\mathrm{draft}}$

Ross, M.L. 2004b. What do we know about natural resources and civil war? Journal of Peace Research 41(3): 337-356.

Rosser, A. 2006. The political economy of the resource curse: a literature survey. IDS Working Paper 268, Brighton, UK: Institute of Development Studies.

Rostow, W.W. 1961. The stages of economic growth: a non-communist manifesto. Cambridge: Cambridge University Press.

Sachs, J.D. and A. Warner. 1995. Economic reform and the process of global integration. Brookings Papers on economic activity. 1: 1-118.

Shaxson, N. 2005. New approaches to volatility: dealing with the resource curse in sub Saharan Africa. International Affairs 81(2): 311-324.

Singer, H.W. 1950. The distribution of gains between investing and borrowing countries. The American Economic Review 40(2): 473-485. 
Snyder, R. 2006. Does lootable wealth breed disorder? A political economy of extraction framework. Comparative Political Studies 39(8): 943-968.

Snyder, R. and R. Bhavnani. 2005. Diamonds, blood, and taxes: a revenue-centered framework for explaining political order. Journal of Conflict Resolution 49(4): 563-597.

Vayda, A.P. 1983. Progressive contextualization: methods for research in human ecology. Human Ecology 11(3): 265-281.

Vayda, A.P. and B.B. Walters. 1999. Against political ecology. Human Ecology 27(1):167-179.

Viner, J. 1952. International trade and economic development: lectures delivered at the National University of Brazil. Gloucestershire: Clarendon Press.

Walker, P.A. 2005. Political ecology: where is the ecology? Progress in Human Geography 29(1): 73-82.

Wantchekon, L. 2002. Why do resource dependent countries have authoritarian governments? Journal of African Finance and Economic Development 2: 57-77.

Watts, M.J. 2007. Petro-insurgency or criminal syndicate? Conflict and violence in the Niger Delta. Review of African Political Economy 34(114): 637-660. draft

Wheeler, D. 1984. Sources of stagnation in sub-Saharan Africa. World Development 12(1): 1-23.

Wick, K. and E.H. Bulte. 2006. Contesting resources, rent seeking, conflict and the natural resource curse. Public Choice 128(3): 457-476. $\underline{\text { draft }}$

\begin{abstract}
The last sixty years have seen a significant shift away from seeing resource wealth as a key component of positive macro-economic reform, to acceptance of the negative impacts that an abundance of, or dependence on, natural resources can have on security, economic growth, and the development of accountable political institutions. The appropriation and extraction of natural resources emerge as expressions of complex relations existing within and between states, institutions and actors. At the same time, the attention given to this potential 'resource curse' has precipitated a number of critiques that challenge not only the data and statistical methods used to link resource wealth with negative development outcomes, but also the theoretical foundation and relevance of studies that reduce complex socio-political and economic relations to the presence of specific resources. This article draws on key literature from the field of political ecology to demonstrate how the concept of 'nature' has been omitted from these discussions. Critical analysis of 'nature' can refine the theoretical foundation and practical application of the 'resource curse' thesis. By re-inserting, re-politicizing and re-localizing the concept of nature we can include local production and consumption in the analysis, while also highlighting the link between our understanding of natural resources and historically rooted discourses of 'proper-use.'
\end{abstract}

Key Words: Resource curse, political ecology, security, nature

\title{
Résumé
}

Les soixante dernières années ont vu un changement significatif loin de l'identification d'une abondance de ressources naturelles comme un élément clé de la réforme macro-économique positif. Maintenant, on accepte les impacts négatifs que l'abondance de (ou la dépendance) des ressources naturelles peut avoir sur la sécurité, la croissance économique et le développement des institutions politiques responsables. L'appropriation et l'extraction des ressources naturelles sont considérées comme des expressions de relations complexes qui existent au sein et entre les Etats, les institutions et les acteurs. Dans le même temps, l'attention portée à ce potentiel «malédiction des ressources» a précipité un certain nombre de critiques qui remettent en question les données et les méthodes statistiques utilisées pour lier la richesse des ressources avec les résultats de développement négatives, et aussi le fondement théorique et la pertinence des études qui permettent de réduire complexe relations socio-politiques et économiques à la présence de ressources spécifiques. Cet article s'appuie sur la littérature clé de l'écologie politique pour démontrer comment le concept de «nature» a été omis dans ces discussions. Une analyse critique de la «nature» peut affiner les fondements théoriques et les applications pratiques de la thèse de la «malédiction des ressources». En réinsérant, re-politiser et relocaliser le concept de nature, nous pouvons inclure la production locale et la consommation dans l'analyse, tout en soulignant le lien entre notre connaissance des ressources naturelles et des discours historiquement enracinées de «bon usage».

Mots clés: la malédiction des ressources, l'écologie politique, de la sécurité, de la nature 


\section{Resumen}

Los últimos sesenta años han presenciado un cambio significativo, al cambiarse la percepción de la riqueza de recursos de un componente clave de la reforma macroeconómica a aceptarse el impacto negativo que la abundancia de recursos naturales, o una dependencia de los mismos, puede tener sobre la seguridad, el crecimiento económico y el desarrollo de instituciones políticas que deban responder de sus acciones. La apropiación y extracción de recursos naturales emerge como la expresión de relaciones complejas entre partes de una nación, estados, instituciones y otros actores. Al mismo tiempo, la atención prestada a esta potencial "maldición del recurso" ha dado lugar a numerosas críticas que ponen en duda no solo los datos y métodos estadísticos usados para relacionas riqueza de recursos con resultados negativos en el desarrollo, sino también los fundamentos teóricos y la relevancia de los estudios que reducen a la presencia de recursos específicos complejas relaciones socio-políticas y económicas. Este artículo toma como base literatura básica en el campo de la ecología política para demostrar cómo se ha omitido el concepto de "naturaleza" de estas discusiones. El análisis crítico de "naturaleza" puede refinar la fundamentación teórica y la aplicación práctica de la tesis de la "maldición del recurso". Mediante la reinserción, repolitización y relocalización del concepto de naturaleza es posible incluir la producción y el consumo local en el análisis, al mismo tiempo que enfatizar el enlace entre nuestro entendimiento de los recursos naturales y discursos de raíz histórica del "uso propio".

Palabras clave: Maldición del recurso, ecología política, seguridad humana, gobernanza, naturaleza 